\title{
Do dry ledges reduce the barrier effect of roads?
}

\author{
Pablo Villalva ${ }^{\mathrm{a}, *}$, Dyana Reto ${ }^{\mathrm{b}}$, Margarida Santos-Reis ${ }^{\mathrm{b}}$, Eloy Revilla ${ }^{\mathrm{a}}$, Clara Grilo ${ }^{\mathrm{a}, \mathrm{b}, \mathrm{c}}$ \\ a Departamento de Biología de la Conservación, Estación Biológica de Doñana-CSIC, Calle Américo Vespucio s/n. E-41092 Sevilla, España \\ ${ }^{\mathrm{b}}$ Universidade de Lisboa, Centro de Biologia Ambiental/Departamento de Biologia Animal, Faculdade de Ciências. C2 5 $1749-016$ Lisboa, Portugal

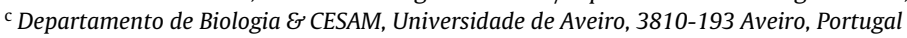

Keywords:

Retrofitting culverts

Mitigation measures

Mesocarnivores

Road permeability

\begin{abstract}
A B S T R A C T
Wildlife crossing structures combined with fencing seek to improve permeability and habitat connectivity across roads and reduce wildlife-vehicle collisions. However, the presence of water inside culverts can seriously limit their effectiveness. The implementation of dry ledges can be a good measure to allow crossing when flooded. So far, there is a lack of knowledge on the effectiveness of dry ledges combined with fencing for a wide diversity of vertebrates. The main goal of this study is to evaluate how the presence of dry ledge affect culvert use for Mediterranean mesocarnivores (red fox Vulpes vulpes, stone marten Martes foina, European badger Meles meles, European otter Lutra lutra and common genet Genetta genetta). Between January and March 2008, wooden dry ledges were placed in 15 of 32 surveyed culverts. Additionally 100 meters of small mesh size and buried fences were installed along each side of all culverts. During one year we used video surveillance and track-plates to detect crossing events over seven consecutive nights per season in each monitored culvert. We evaluate the relative importance of dry ledges on culvert use and compare the number of road-kills within a $100 \mathrm{~m}$ buffer radius around the culverts before and after fence installation and culverts that were never fenced (control culverts). Although different species responded to culvert features differently, the presence of dry ledges was the most relevant feature explaining crossing events, in particular, for stone martens and genets. The fencing used did not reduce mammals road-kill prevalence. Our results imply that in order to improve culvert use, road managers should take into account the placement of ledges on culverts that remain flooded most of the year (more than $3 \mathrm{~cm}$ of water-depth). We also suggest exploring the role of ledge size and construction materials to increase the likelihood of being used by foxes and badgers.
\end{abstract}

\section{Introduction}

The negative effects of high traffic roads on animal populations have been intensively described in the last decades (Cain et al., 2003; Clevenger et al., 2003; Farhig and Rytwinski, 2009; Forman and Alexander, 1998; Klar et al., 2009). For many species roads create barriers to migration, dispersal and genetic exchange through the inhibition of crossing movements and the additional mortality due to collisions with vehicles (e.g. McGregor et al., 2008; Rondinini and Doncaster, 2002; Shepard et al., 2008; Strasburg, 2006; Rytwinski and Fahrig, 2012). Nowadays, there is a growing interest to mitigate these impacts by means of a wide variety of measures (Corlatti et al., 2008; Glista et al., 2009). Examples are the construction of underpasses and overpasses to maintain landscape

\footnotetext{
* Corresponding author.

E-mail addresses: sostingy@yahoo.es (P. Villalva), dyana.pereira@gmail.com (D. Reto), mmreis@fc.ul.pt (M. Santos-Reis), revilla@ebd.csic.es (E. Revilla), claragrilo@ua.pt (C. Grilo).
}

connectivity (Clevenger and Waltho, 2000; Foster and Humphrey, 1995) and the use of fences, one-way gates, reflectors and/or warning signs (Aresco, 2005; D'Angelo et al., 2006; Klar et al., 2009; Reed et al., 1974; Sullivan et al., 2004; Ujvári et al., 1998) to reduce mortality.

Special attention has been paid to the use of drainage culverts as potential underpasses, due to the large number present along roads, their relative low cost (Mata et al., 2008), and to their welldocumented use by many terrestrial vertebrates (Clevenger et al., 2001; Grilo et al., 2008; Ng et al., 2004; Rodriguez et al., 1996; Yanes et al., 1995). Nevertheless, the presence of water inside many culverts may limit their use as passages (Serronha et al., 2012). The installation of dry ledges can be a good management measure to allow crossing when flooded (e.g. Meaney et al., 2007). In spite of this, for many vertebrates such as carnivores, the information on the effectiveness of dry ledges in terms of increased permeability is still scarce. Equally, there is few information on the effectiveness of fencing road sections for carnivores and small mammals. Jaeger and Fahrig (2004) suggested that fencing may not be worth due to high costs and the limitation of animal movements which may be 


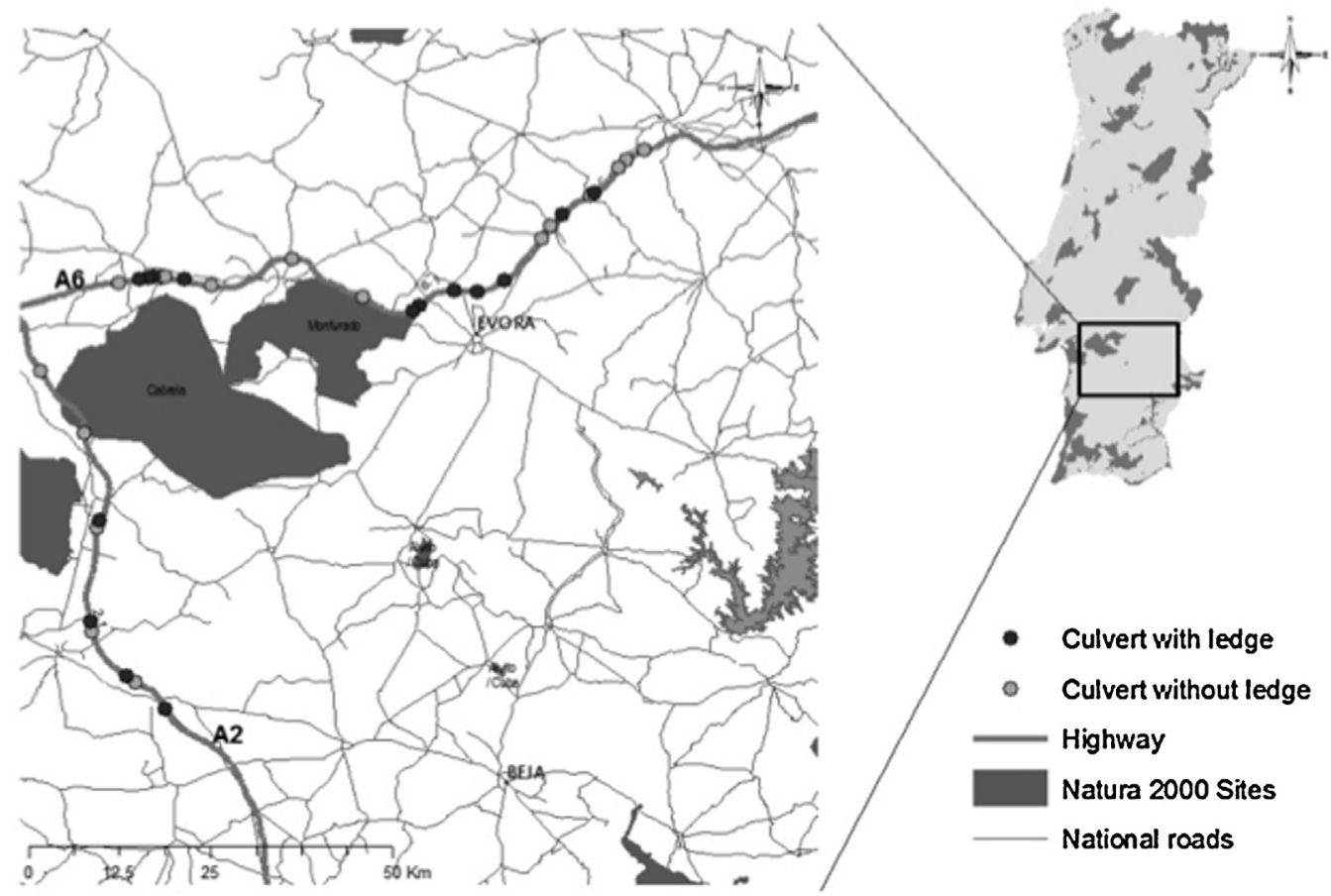

Figure 1. Study area and location of the monitored passages along the A2 and A6 highways in Portugal.

even more harmful than mortality. One interesting solution is fencing just the road sections with high incidence of road-kills (e.g. Klar et al., 2009) but when road-kills data is limited, we argue that the complementary use of fences combined with crossing structures, as suggested by several authors (e.g. Boarman et al., 1997; Dodd et al., 2004), may be also effective in reducing the road mortality.

The main goal of this study is to evaluate the effectiveness of dry ledges combined with fencing for mesocarnivores in culverts flooded part of the year by addressing the following questions: 1) what is the relative importance of ledges combined with fencing on culverts use? 2) which water-related descriptors influence the use of ledges? and 3) does complementary fencing reduce mammals mortality? We expect the effectiveness to be different according to species life history traits. A priori, we expect dry ledges to be more effective for smaller and water-reluctant species. Knowledge on these topics will provide support for a better understanding on the effectiveness of dry ledges, and therefore, reduce the overall impact of the road network in a cost-effective way.

\section{Methods}

\subsection{Study area}

The study was carried out in Alentejo province of southern Portugal along A2 (95 km) and A6 (150 km) highways sections (the intersection of both highways is located at $38^{\circ} 36^{\prime} \mathrm{N}$ and $8^{\circ} 38^{\prime} \mathrm{W}$, Fig. 1). These highways under a private concession (BRISA AutoEstradas de Portugal, S.A.) were built between 1996 and 2001 and have an annual average daily traffic of 13,949 vehicles and annual average night time (6pm to 6am) traffic of 5536 vehicles. On average, there are two crossing structures per kilometer of which more than $70 \%$ are drainage culverts. Both highways have livestock exclusion fencing (unburied, $150 \mathrm{~cm}$ height with $12 \mathrm{~cm}$ mesh size) which is generally ineffective in preventing crossing for almost all mammals (Grilo et al., 2009).

Land cover in the vicinity of the highway is representative of the typical Mediterranean landscape dominated by cork oak woodlands (Quercus suber) and holm oak (Q. ilex) that alternate with cereal crops. Excluding the two largest cities in the region, which have a population density of 1980 inhabitants $/ \mathrm{km}^{2}$, the population density in the study area is 21 inhabitants $/ \mathrm{km}^{2}$. The studied highways border four Rede Natura 2000 sites (Sado, Cabrela, Monfurado and Caia) each of which host a high carnivore richness (Santos-Reis and Petrucci-Fonseca, 1999).

\subsection{Data collection}

We surveyed 32 culverts along segments of these two highways: 13 circular culverts ( 1 and $1.5 \mathrm{~m}$ of diameter) and 19 squared culverts (ranging from $2 \times 2$ to $4 \times 4 \mathrm{~m}$ ). Between January and March 2008 , wooden dry ledges of $50 \mathrm{~cm}$ width were placed $30 \mathrm{~cm}$ from the ground in 15 culverts: three circular culverts ( 1 and $1.5 \mathrm{~m}$ of diameter) and 12 squared culverts (ranging from $2 \times 2$ to $4 \times 4 \mathrm{~m}$ ). Ledges were installed in those culverts with a higher probability of being flooded during the rainy seasons (average water depth $5 \pm 4 \mathrm{~cm}$ and average water cover $54 \pm 30 \%$ ). In April 2008 and in addition to the livestock exclusion fences, 100 meters of small mesh size fences $(2.5 \mathrm{~cm}$ wide) were installed $(50 \mathrm{~cm}$ of height and buried $50 \mathrm{~cm}$ to avoid under-passing) along each side of 32 culverts surveyed, totalizing $12.8 \mathrm{~km}$ of fence, and 32 other similar culverts (with the same shapes and sizes as described above) were randomly selected in order to better control the role of fencing.

We used video surveillance and track-pads to detect the use of culverts by mesocarnivores. Two cameras with movement and heat sensors were oriented towards one entrance of each culvert and a fine layer of marble dust, with $120 \mathrm{~cm}$ of length, was placed covering the entire culvert width. Monitoring was conducted over seven consecutive nights per season in each culvert for one year after ledge installation. Every day video batteries were replaced and track pads were checked. Culverts were described in terms of spatial and temporal features over the monitoring period (Table 1). Spatial features include culvert features (presence of dry ledge, vegetation at the entrance, distance from culvert entrance to highway and openness), and the surrounding landscape within a buffer of 
Table 1

Summary of variables included in the candidate models (description of the variables, mean and range).

\begin{tabular}{|c|c|c|}
\hline Variables description & Mean & Range \\
\hline \multicolumn{3}{|l|}{ SPATIAL FEATURES } \\
\hline \multicolumn{3}{|l|}{ Culvert features } \\
\hline Ledge & & $\begin{array}{l}\text { without ledge }=0 \\
\text { with ledge }=1\end{array}$ \\
\hline Openness (height $\mathrm{x}$ width) $\left(\mathrm{m}^{2}\right)$ & 5.7 & $1-12$ \\
\hline Vegetation height at the entrance $(\mathrm{m})$ & 0.43 & $0-9.75$ \\
\hline $\begin{array}{l}\text { Distance from culvert entrance to } \\
\text { highway }(\mathrm{m})\end{array}$ & 14.8 & $0-70$ \\
\hline \multicolumn{3}{|l|}{ Surrounding landscape (300 m buffer) } \\
\hline Cork oak woodland (\%) & 38.6 & $0-100$ \\
\hline Undestorey vegetation (\%) & 24.4 & $0-100$ \\
\hline Urban areas (\%) & 1 & $0-100$ \\
\hline Riparian vegetation type & - & shrubs $=1 ;$ trees $=2$ \\
\hline Position of riparian vegetation & - & $\begin{array}{l}\text { paralel =1; } \\
\text { perpendicular = } 2\end{array}$ \\
\hline \multicolumn{3}{|l|}{ TEMPORAL FEATURES } \\
\hline Weather & 1.86 & $\begin{array}{l}\text { dry }=1 ; \\
\text { wet }=2 ; \text { rainy }=3\end{array}$ \\
\hline Water depth inside $(\mathrm{cm})$ & 3.4 & $0-50$ \\
\hline Water depth outside $(\mathrm{cm})^{*}$ & 4.1 & $0-40$ \\
\hline Water cover (\%) ${ }^{\mathrm{a}}$ & 36.5 & $0-100$ \\
\hline Traffic (vehicles/day) & 192 & $66-574$ \\
\hline Season $^{\mathrm{b}}$ & - & $\begin{array}{l}\text { Spring, Summer, } \\
\text { Fall, Winter }\end{array}$ \\
\hline
\end{tabular}

a used exclusively for the role of water variables on dry ledge use.

b whenever season was a significant variable, it was transformed into binary dummy variables: presence/absence of spring, summer, fall or winter.

$300 \mathrm{~m}$ (percentage of cork oak woodland, understory vegetation, urban areas and riparian vegetation type and position). Temporal features comprise weekly changes such as weather, water cover, water depth inside and outside the culvert, traffic at night and season surveyed (Table 1). We used mammals' road-kill data recorded by BRISA staff in charge of the daily maintenance of the highways in the period of 20 months before and after fencing.

\subsection{Data analysis}

We used Generalized Linear Mixed Models (GLMM) to test the effect of spatial and temporal features on culvert use and a logit link with species crossing (crossing vs. no crossing along each week representing one season) as response variable (Zuur et al., 2009) and culvert ID as a random effect to avoid pseudo-replication among culverts and to control for any idiosyncratic effect associated to each culvert (e.g., shape or size).

First, we analyzed the effect of the presence of dry ledges and several additional variables on the probability of culvert use by comparing crossing events presence and absence. A set of models was designed for each species guided by four general hypotheses: 1) culvert features influence their use by carnivores; 2) culvert use is explained by the surrounding landscape; 3 ) weekly changing features or seasonality affect culvert use; or 4) the combination of the previous hypotheses explain culvert use. We also constructed a null model that includes no explanatory variables. Prior to modeling, we searched for confounding effects among culvert attributes using Spearman's rank correlation (Zar, 1999) in order to reduce the effects of multicollinearity. From any pair of independent variables that reported $r>|0.5|(p<0.05)$ we removed the independent variable with the smallest correlation with the response variable. For example, culvert length was highly correlated with distance to the highway, which in turn explained better the use of culverts and therefore was retained for further analyses.Models were ranked according to Akaike's Information Criterion (AIC) (Burnham and Anderson, 2002). Model accuracy was examined to assess how
Table 2

Parameter estimates ( $\beta$, standard error S.E. and p-values) for the best models explaining the probability of using culverts to cross the highways.

\begin{tabular}{llrlr}
\hline Species model & Variables & $\beta$ & S.E. & $p$-value \\
\hline \multirow{2}{*}{ red fox } & intercept & -1.059 & 0.6090 & 0.081 \\
& Ledge & -1.397 & 0.860 & 0.104 \\
& Winter & -1.757 & 0.846 & 0.038 \\
\multirow{5}{*}{ stone marten } & 1.143 & 0.565 & 0.040 \\
& Fall & -1.814 & 0.5600 & 0.001 \\
& intercept & 1.292 & 0.589 & 0.028 \\
& Ledge & 0.438 & 1.186 & 0.235 \\
badger & Ripiarian vegetation position & -0.876 & 0.544 & 0.107 \\
& Summer & 0.667 & 0.307 & 0.029 \\
& intercept & -1.170 & 0.438 & 0.007 \\
otter & Ledge & -0.292 & 0.115 & 0.011 \\
& Water depth inside & -2.368 & 0.890 & 0.007 \\
& intercept & -0.493 & 0.2677 & 0.065 \\
& Weather & 0.784 & 0.412 & 0.056 \\
genet & Riparian vegetation type & 0.647 & 0.421 & 0.124 \\
& Riparian vegetation position & -5.511 & 1.021 & $<0.001$ \\
& intercept & 1.532 & 0.578 & 0.008 \\
& Ledge & 0.054 & 0.025 & 0.035 \\
& Verge length & 0.739 & 0.418 & 0.076 \\
& Riparian vegetation type & 0.010 & 0.002 & $<0.001$ \\
\hline & Traffic & & & \\
\hline
\end{tabular}

well the best model $(\triangle \mathrm{AIC}=0)$ fits the data using quantile-quantile plots. Spatial autocorrelation of residuals was analyzed with spline correlograms with $95 \%$ pointwise boostrap.

We estimate the likelihood of ledge use within the 15 culverts with ledges installed in relation to water features: the percentage of water in the culvert (water cover), water depth inside and depth outside the culvert (Table 1 ). We run univariate GLMM with a logistic link using species ledge use (ledge use $=1$ and no use $=0$ in a given week) as response variable and culverts as a random effect as explained above.

Finally, we evaluated the effect of the additional fencing to reduce mammals mortality by addressing two hypotheses: H1) no differences in mortality are explained by local population density changes. H2) differences in mortality are explained by the effect of fencing. We compared the number of road-kills within a buffer of $100 \mathrm{~m}$ radius around 32 fenced culverts occurred during 20 months before and after fencing. If we found differences between this time periods, we compared data for each period with 32 other culverts with similar shape and size that were never fenced in order to control stochastic population density changes. Both analyses took into account the surrounding landscape expressed by the existence of forest within the $100 \mathrm{~m}$ buffer around the culvert. Hypotheses ( $\mathrm{H} 1$ and $\mathrm{H} 2$ ) were tested using a GLMM with a Poisson distribution, where the number of road-kills was the response variable and culverts a random effect.

We performed all statistical analysis using lme4 (Bates et al., 2011), glmmML (Broström and Holmberg, 2011), ncf (Bjornstad, 2009) packages in R version 2.13.2 (R Development Core Team, 2011).

\section{Results}

We recorded a total of 397 successful mesocarnivore crossings ( 0.44 crossings/culvert/day). Of these crossings 30\% were performed by Eurasian badger, $23 \%$ by stone marten, $12 \%$ by Eurasian otter, $20 \%$ by common genet and $15 \%$ by red fox.

The best models show that the presence of a dry ledge was associated to the use of culverts by all non-aquatic species (Table 2 , Appendix A). The importance of the remaining variables varied among species. In fact, this feature has AIC weights $\left(\mathrm{AIC}_{\mathrm{wi}}\right)$ ranging from 0.42 to 0.85 (Appendix $B$ ). Interestingly, stone marten and genet crossings were positively associated to the presence of 
dry ledges while red fox and badger crossings were associated to the absence of dry ledges (Table 2). Even though we expected differences in culvert use among seasons between species, only the red fox best model show that fox crossings were positively associated with fall $\left(\mathrm{AIC}_{\mathrm{wi}}=0.77\right)$, and had a negative relationship with winter $\left(\mathrm{AIC}_{\mathrm{wi}}=0.80\right)$, and stone marten crossings were negatively related with summer $\left(\mathrm{AIC}_{\mathrm{wi}}=0.58\right)$ (Table 2$)$. The absence of water influenced positively badger crossings with a weight AIC of 0.86 (Table 2). Riparian trees and their orientation to the culvert seem to be positively associated with otter crossings $\left(\mathrm{AIC}_{\mathrm{wi}}=0.42\right.$ and 0.50 , respectively). In contrast, during dry weeks otters seemed to avoid using culverts (Table 2). Surprisingly, we observed that traffic volume influence positively genet crossings ( AIC weight $=0.72$ ) as well the distance from the culvert entrance to highway (AIC weight $=0.71$ ). Spline correlograms with $95 \%$ bootstrap showed no spatial autocorrelation in any species (results not shown). Quantile-quantile plots show that no major departures from model assumptions were detected.

In general, all species except otters used more the ledge than the ground in the rainy seasons (Figure 2). Interestingly, stone martens and genets started to use the ledges immediately after the ledge placement (in summer). Few data for red fox crossings $(n=11)$, badger crossings $(n=5)$ and otter crossings $(n=8)$ regarding water depth and width precluded including them in further analyses. Models for stone martens and genets show that water depth was the variable that better explains the use of dry ledges
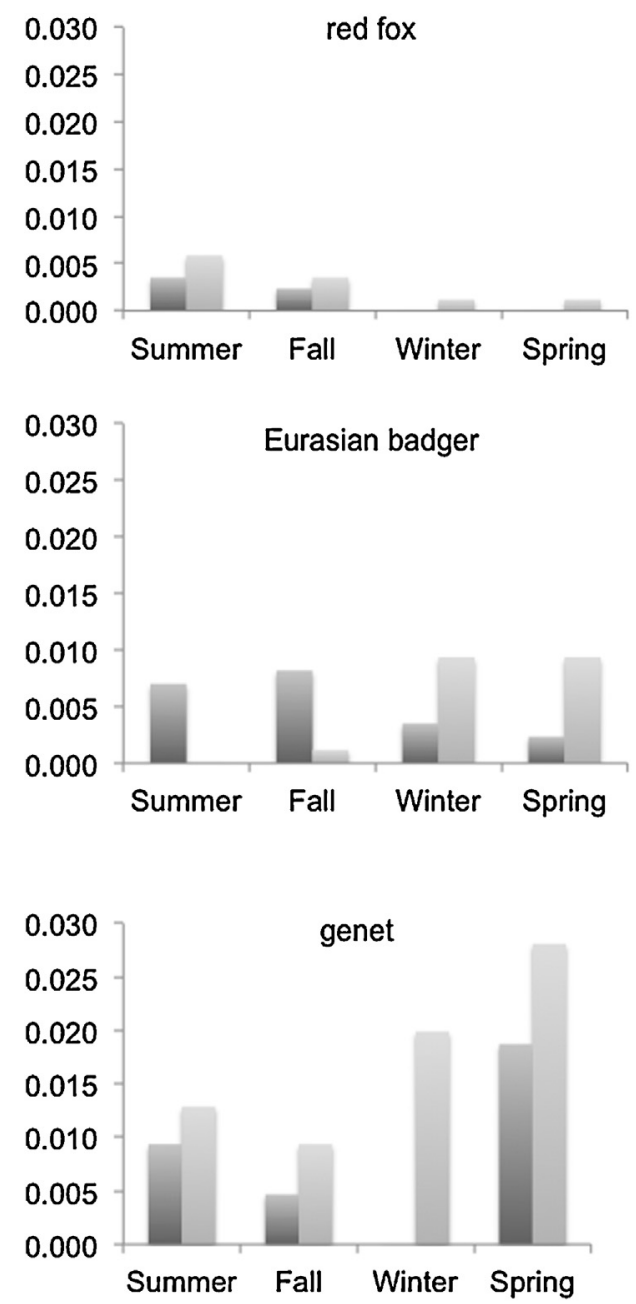

Table 3

Univariate analysis using GLMM for the likelihood of ledge use: Akaike Information Criterion (AIC), coefficient estimate $(\beta)$, standard error (S.E.), test $Z$ significance ( $p$ value) for stone marten $(n=62)$ and genet $(n=38)$

\begin{tabular}{|c|c|c|c|c|c|}
\hline Species & Variables & AIC & $\beta$ & S.E. & p-value \\
\hline \multirow[t]{7}{*}{ stone marten } & intercept & & -0.14 & 1.34 & 0.91 \\
\hline & water cover & 53 & 0.05 & 0.02 & 0.01 \\
\hline & intercept & & -0.30 & 1.17 & 0.79 \\
\hline & water depth inside & 48 & 5.67 & 3.56 & 0.11 \\
\hline & intercept & & 1.67 & 2.13 & 0.43 \\
\hline & water depth outside & 57 & 0.73 & 0.35 & 0.04 \\
\hline & Null & 71 & 1.87 & 0.81 & 0.02 \\
\hline \multirow[t]{7}{*}{ genet } & intercept & & 0.23 & 0.65 & 0.71 \\
\hline & water cover & 38 & 0.02 & 0.01 & 0.03 \\
\hline & intercept & & 0.71 & 0.69 & 0.30 \\
\hline & water depth inside & 41 & 0.38 & 0.32 & 0.23 \\
\hline & intercept & & -0.24 & 0.65 & 0.71 \\
\hline & water depth outside & 33 & 1.54 & 0.83 & 0.06 \\
\hline & Null & 43 & 1.34 & 0.59 & 0.02 \\
\hline
\end{tabular}

(Table 3). However, stone marten was more influenced by water depth inside, and genet by water depth outside the culvert. Figure 3 show that stone martens more likely used dry ledges above $1 \mathrm{~cm}$ of water depth inside the culvert while genets responded better to water depth above $3 \mathrm{~cm}$ outside.

Mammal road mortality was very similar before (20 roadkills) and after (19 road-kills) fencing period within the $100 \mathrm{~m}$ radius around the 31 fenced culverts. We found no diferences
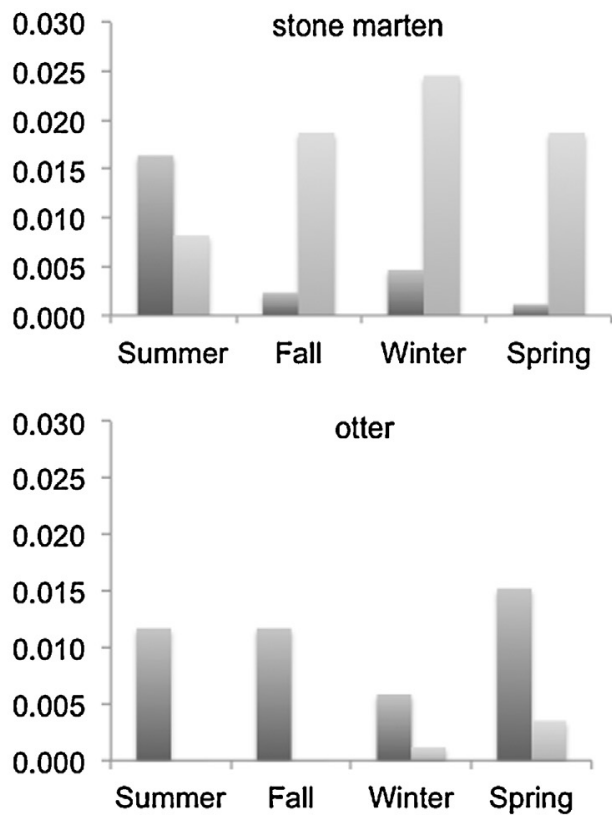


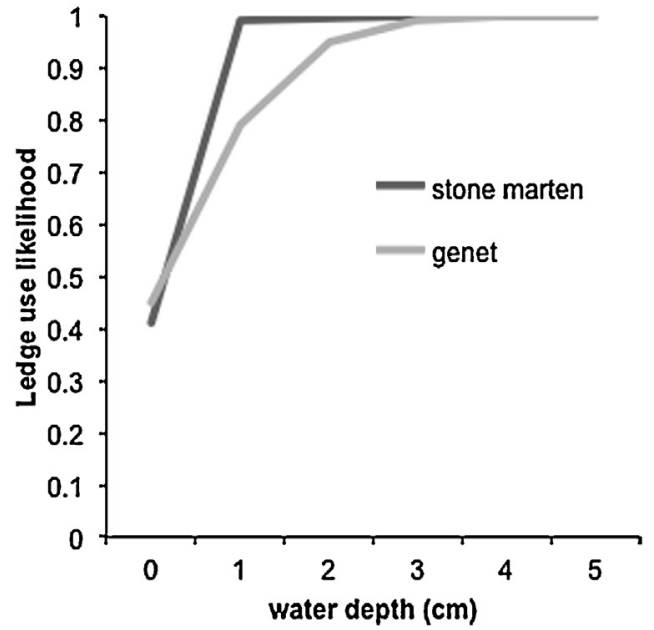

Figure 3. Probability of ledge use for stone marten (black line) and genet (grey line) in relation to water depth.

between fenced and unfenced culverts before fence implementation ( 20 roadkills) and scarce differences appeared between these culverts after fencing (19 and 13 roadkills respectively). In particular, small mammals, mostly rabbits (Oryctolagus cunniculus), were road-killed in similar numbers before ( 7 road-kills) and after (9 road-kills) fencing. Equally, no big differences were found on the records of carnivores before $(n=12)$ and after fencing $(n=9)$ in fenced culverts and neither in unfenced ones $(n=4$ and $n=5$ respectively). As expected from the raw numbers, the null model showed the lowest AIC (Appendix D).

\section{Discussion}

The recent development of landscape ecology emphasizes the importance of habitat connectivity for population viability (Clergeau and Burel, 1997). Road planning efforts towards reducing barrier effects and wildlife-vehicle collisions are critical for a sustainable road network management (Forman et al., 2003). To ensure successful mitigation it is important to identify the species favored by these measures and to examine the best design and placement. Our results highlight the importance of dry ledges in drainage culverts to maintain habitat connectivity for forest dwelling species such as stone marten and genet and the need of further research on ledge design in particular for foxes and badgers as well fence design and placement to prevent mammals -vehicle collisions. In fact, there is considerable evidence suggesting that water prevents culvert use by stone martens and genets and consequently dry ledges seem to be a useful measure to promote their use. We noticed that all species with the exception of otters used more dry ledges during the rainy seasons, suggesting ledges are used when water is present. Despite the correlation between water cover and depth, the later seems to be more important to explain the likelihood of use of dry ledges by stone martens and genets. Interestingly, stone martens and genets used ledges immediately after installation and even during the dry period (summer), which suggests that they respond very well to this new structure. As ledges were not randomly installed but rather in those culverts more likely to be flooded for longer, the selected culverts are positively associated to streams and their associated riparian vegetation. In fact, variables related with vegetation in the entrance (vegetation height and riparian vegetation) had also an important role on culvert use. One explanation for this fact is that, being forestdwelling species, stone martens and genets, tend to use culverts with developed vegetation outside the culverts because it provides cover, shelter and prey (Grilo et al., 2008; Matos et al., 2008; Rodriguez et al., 1996) but only when dry. Unexpectedly, red foxes and badgers seem to avoid culverts with dry ledges. Three reasons may explain this finding. Both foxes and badgers may need time to adapt to new structures. In fact, we documented that badgers only started to use the ledges on a regular basis four months after ledge installation (fall 2008). Alternatively, the presence of a ledge may reduce the openness ratio of the culverts. Several studies recorded that carnivores tend to use larger culverts (Grilo et al., 2008, Mata et al., 2008, 2009) and the presence of ledges may reduce openness ratio, which may decrease the likelihood of culvert use. Finally, sampling design may indicate that foxes and badgers prefer culverts that are dry along the year irrespective of the presence of ledges.

We also detected that traffic disturbance seems to influence genet crossings which seems to prefer culverts within high traffic volume sections. Nevertheless, genets select those culverts located far away from the highway (those with a wide road verge). Interestingly, the relationship between genet crossings and culverts far from the road pavement was also found by Ascensão and Mira (2006). Unexpectedly, we found weak support for the hypothesis that seasons corresponding to higher mobility and abundance increase the likelihood of culvert use, except for the red fox. Foxes are more likely to use culverts in fall, maybe because juveniles are still in dispersion (Blanco, 1998). Winter seems to be the season with fewer crossings which is supported by a previous study on mortality in the same highways (Grilo et al., 2009), where we found fewer records, suggesting low activity rates in this season.

We suggest to place ledges wherever there are no suitable crossing structures to provide safe highway crossings within the distance of the species daily movements (Bissonette and Adair, 2008). In the case of stone martens and genets, if there are no dry crossing structures within $1000 \mathrm{~m}$ (average daily movements according to home-range estimates based on Santos-Reis et al., 2004), we recommend to place at least one dry ledge.

In the light of the small sample, road-kill results must be interpreted as indicative but not fully conclusive. Opposite to the expectation, complementary fencing did not reduce the road-kill rates. Several factors may explain these results. Firstly, implementation of the small mesh buried fence was not long enough, and just $100 \mathrm{~m}$ on each side may be too short, in particular, for mesocarnivores with large spatial requirements (Cavallini and Lovari, 1994; Genovesi et al., 1997; Lindstedt et al., 1986). In fact individuals could walk around the fence and enter the road without even taking a long detour. Secondly, fences do not have any structure to prevent climbing as Klar et al. (2009) proposed for the wildcat and this does not limit the trespassing capacity of individuals able to climb it. However, we could expect differences in ground dwelling species because fences were buried, in particular for species with small home-ranges. Neither this was the case, showing the inefficacy of this fencing design. Finally, the reduced duration of the study may not allow us to find differences in the road-kill rates.

\section{Conclusions}

In summary, we found that dry ledges can be a useful management action to improve the use by some species of flooded drainage culverts as crossing structures. To do so, we should take into account not only the number and complementary sizes of crossing structures (Mata et al., 2008) but also identify where streams intersect with roads and place ledges in structures likely to be flooded (minimum $3 \mathrm{~cm}$ depth) during most or part of the year. Additionally, we strongly recommend exploring the role of ledge design and 
construction materials to increase the likelihood of being used by other species.

\section{Acknowledgements}

This study was conducted in the framework of a research project under a protocol between BRISA Auto-Estradas de Portugal S.A and Centro de Biologia Ambiental from Lisbon University. Special thanks to Ana Rita Mateus and Ana Serronha that perform the fieldwork in the beginning of this study and BRISA employees that collect the road kill data.

\section{Appendix A. Supplementary data}

Supplementary data associated with this article can be found, in the online version, at http://dx.doi.org/10.1016/ j.ecoleng.2013.04.005.

\section{References}

Aresco, M.J., 2005. Mitigation measures to reduce highyway mortality of turtles and other herpeto fauna at North Florida Lake. J. Wildl. Manage. 69, 549-560.

Ascensão, F., Mira, A., 2006. Factors affecting culvert use by vertebrates along two stretches of roads in southern Portugal. Ecol. Res. 22, 57-66.

Bissonette, J.A., Adair, W., 2008. Restoring habitat permeability to roaded landscapes with isometrically-scaled wildlife crossings. Biol. Conserv. 141, 482-488.

Blanco, J.C., 1998. Mamíferos de España. I Insectívoros, Quirópteros, Carnivoros de la Peninsula ibérica, Baeares y Canarias ed. Geoplaneta.

Boarman, W.I., Sazaki, M., Jennings, W.B., 1997. The Effect of Roads, Barrier Fences, and Culverts on Desert Tortoise Populations in California, USA. In: Van Abbema, J. (Ed.), Proceedings: Conservation, Restoration, and Management of Tortoises and Turtles-An International Conference. New York Turtle and Tortoise Society, New York, pp. 54-58.

Bjornstad, O.N., 2009. ncf: spatial nonparametric covariance functions. R package version 1. 1-3. http://CRAN.R-project.org/package=ncf. Accessed $2012 \mathrm{Jul} 20$.

Broström, G., Holmberg, H., 2011. glmmML: Generalized linear models with clustering. R package version $0.82-1$. http://CRAN.R-project.org/package=glmmML Accessed 2012 Jul 20.

Burnham, K.P., Anderson, D.R., 2002. Model Selection and Multimodel Inference: A Practical Information-Theoretic approach, 2nd ed. Springer.

Cain, A.T., Tuovila, V.R., Hewitt, D.G., Tewes, M.E., 2003. Effects of a highway and mitigation projects on bobcats in Southern Texas. Biol. Conserv. 114, 189-197.

Cavallini, P., Lovari, S., 1994. Home range, habitat selection and acivity of the red fox in a Mediterranean coastal ecotone. Acta. Theriol. 39, 279-287.

Clergeau, P., Burel, F., 1997. The role of spatio-temporal patch connectivity at the landscape level: an example in a bird distribution. Landscape Urban Plan. 38, 37-43.

Clevenger, A.P. Waltho, N., 2000. Factors Influencing the Effectiveness of Wildlife Underpasses in Banff National Park. Alberta, Canada. Conserv. Biol. 14, 47-56.

Clevenger, A.P., Chruszcz, B., Gunson, K., 2001. Drainage culverts as habitat linkages and factors affecting passage by mammals. J. Appl. Ecol. 38, 1340-1349.

Clevenger, A.P., Chuszcz, B., Gunson, K.E., 2003. Spatial patterns and factors influencing small vertebrate fauna road-kill aggregations. Biol. Conserv. 109, 15-26.

Corlatti, L., Hackleander, K., Frey-Roos, F., 2008. Ability of Wildlife Overpasses to Provide Connectivity and Prevent Genetic Isolation. Conserv. Biol. 23, 548-556.

D’Angelo, G.J., Gallagher, G.R., Osborn, D.A., Miller, K.V., Warren, R.J., 2006. Evaluation of Wildlife Warning Reflectors for Altering White-Tailed Deer Behavior Along Roadways. Wildlife. Soc. B 34, 1175-1183.

Dodd, C.K., Barichivich, W.J., Smith, L.L., 2004. Effectiveness of a barrier wall and culverts in reducing wildlife mortality on a heavily traveled highway in Florida. Biol. Conserv. 118, 619-631.

Farhig, L., Rytwinski, T., 2009. Effects of roads on animal abundance: an empirical review and synthesis. Ecology and Society 14 (1), 21 [online] URL: http://www.ecologyandsociety.org/vol14/iss1/art21/. Accessed 2012 Jul 20.
Forman, R.T., Alexander, L., 1998. Roads and their major ecological effects. Annu. Rev. Ecol. Syst. 29, 207-231.

Forman, R.T.T., Sperling, D., Bissonette, J.A., Clevenger, A., Cutshall, C., Dale, V., Fahrig L., France, R., Goldman, C., Heanue, K., Jones, J., Swanson, F., Turrentine, T., Winter, T., 2003. Road Ecology: Science and Solutions. Island Press, Washington.

Foster, M.L., Humphrey, S.R., 1995. Use of highway underpasses by Florida panthers and other wildlife. Wildlife Soc B 23, 95-100.

Genovesi, P., Sinibaldi, I., Boitani, L., 1997. Spacing patterns and territoriality of the Stone marten. Can. J. Zool. 75, 1966-1971.

Glista, D.J., DeVault, T.L., DeWoody, J.A., 2009. A review of mitigation measures for reducing wildlife mortality on roadways. Landscape Urban Plan. 91, 1-7.

Grilo, C., Bissonette, J.A., Santos-Reis, M., 2008. Response of carnivores to existing highway culverts and underpasses: Implications for road planning and mitigation. Biodivers. Conserv. 17, 1685-1699.

Grilo, C., Bissonette, J.A., Santos-Reis, M., 2009. Spatial-temporal patterns in Mediterranean carnivore road casualties: Consequences for mitigation. Biol Conserv. 142, 301-313.

Klar, N., Herrmann, M., Kramer-Schadt, S., 2009. Effects and Mitigation of Road Impacts on Individual Movement Behavior of Wildcats. J. Wildl. Manage. 73, 631-638.

Lindstedt, S., Miller, B.J., Buskirk, S.W., 1986. Home range, time and body size in mammals. Ecology 67, 413-418.

Mata, C., Hervas, I., Herranz, J., Suarez, F., Malo, J.E., 2008. Are motorway wildlife passages worth building? Vertebrate use of road-crossing structures on a Spanish motorway. J. Environ. Manage. 88, 407-415.

Mata, C., Hervás, I., Herranz, J., Malo, J.E., Francisco, S., 2009. Seasonal changes in wildlife use of motorway crossing structures and their implication for monitoring programmes. Transportation Res D-TR E 14 (7), 447-452.

Matos, H.M., Santos, M.J., Palomares, F., Santos-Reis, M., 2008. Does riparian habitat condition influence mammalian carnivore abundance in Mediterranean ecosystems? Biodivers. Conserv 18, 373-386.

McGregor, R.L., Bender, D.J., Farhig, L., 2008. Do small mammals avoid roads because of the traffic? J. Appl. Ecol. 45, 117-123.

Meaney, C., Bakeman, M., Reed-Eckert, M., Wostl, E. 2007. Effectiveness of ledges in culverts for small mammal passage. Colorado Department of Transportation, Research Branch. Report No. CDOT-2007-9.

Ng, S.J., Dole, J.W., Sauvajot, R.M., Riley, S.P., Valone, T.J., 2004. Use of highway undercrossings by wildlife in southern California. Biol. Conserv. 115, 499-507.

R Development Core Team (2011). R: A language and environment for statistical computing. R Foundation for Statistical Computing, Vienna, Austria. Available: http://www.R-project.org/Accessed 2012 Jul 20.

Reed, D.F., Pojar, T.M., Woodard, T.N., 1974. Use of One-Way Gates by Mule Deer. J. Wildl. Manage. 38, 9-15.

Rodriguez, A., Crema, G., Delibes, M., 1996. Use of Non-Wildlife Passages Across a High Speed Railway by Terrestrial Vertebrates. J Appl. Ecol. 33, 1527-1540.

Rondinini, C., Doncaster, C.P., 2002. Roads as barriers to movement for hedgehogs. Funct. Ecol. 16, 504-509.

Rytwinski, T., Fahrig, L., 2012. Do species life history traits explain population responses to roads? A meta-analysis. Biol. Conserv. 47, 87-98.

Santos-Reis, M., Petrucci-Fonseca, F., 1999. Carnívoros. In: Mathias, M.L. (Ed.) Mamíferos terrestres de Portugal Continental Madeira e Açores. ICN/CBA, Lisboa Portugal.

Santos-Reis, M., Santos, M.J., Lourenço, S., Marques, T., Pereira, I., Pinto, B., 2004 Chapter 7. Relationships between stone martens, genets and cork oak woodlands in Portugal. In: Harrison, D.J., Fuller, A.K., Proulx, G. (Eds.), Marten and fishers in human altered landscapes. An International perspective. Kluwer Academic Publishers, Massachusetts.

Serronha, A.M., Mateus, R., Eaton, F., Santos-Reis, M., Grilo, C., 2012. Towards effective culvert design: monitoring seasonal use and behavior by Mediterranean mesocarnivores. Environ. Monit. Assess. http://dx.doi.org/10.1007/s10661-012-3020-3.

Shepard, D.B., Kuhns, A.R., Dreslik, M.J., Phillips, C.A., 2008. Roads as barriers to animal movement in fragmented landscapes. Anim. Conserv. 11, 288-296.

Sullivan, T.L., Williams, A.F., Messmer, T.A., Hellinga, L.A., Kyrychenko, S.Y., 2004 Effectiveness of temporary warning signs in reducing deer-vehicle collisions during mule deer migrations. Wildlife Soc B 32, 907-915.

Strasburg, J.L., 2006. Roads and genetic connectivity. Nature 440, 875-876.

Ujvári, M., Baagøe, H.J., Madsen, A.B., 1998. Effectiveness of Wildlife Warning Reflectors in Reducing Deer-Vehicle Collisions: A Behavioral Study. J. Wildl Manage. 62, 1094-1099.

Yanes, M., Velasco, J.M., Suárez, F., 1995. Permeability of roads and railways to vertebrates: The importance of culverts. Biol. Conserv. 71, 217-222.

Zuur, A.F., Ieno, E.N., Walker, N.J., Saveliev, A.A., Smith, G.M., 2009. Mixed Effects Models and Extensions in Ecology with R, 1st edition. Springer. 